\title{
Pengaruh Return on Investment, Net Profit Margin, Dividen Per Share dan Pertumbuhan Aset terhadap Harga Saham Perusahaan Manufaktur
}

\author{
Julianto Fernando ${ }^{1}$, Felisia ${ }^{2}$, Cindy Yulistia ${ }^{3}$, Mohd.Nawi Purba ${ }^{4 *}$ \\ $1,2,3,4)$ Universitas Prima Indonesia \\ juliantofernando19@gmail.com, felisiazhan@gmail.com, cindyyulistia24@gmail.com \\ nawi_purba@yahoo.com
}

*Corresponding Author

Submitted: August 8, 2020

Accepted: November 13, 2020

Published: February 1, 2021

\begin{abstract}
A publicly listed company on the IDX, such as a manufacturing company, must issue shares that can be owned by investors. The stock price is very volatile and can change at any time, even though per Share and Asset Growth on Stock Prices of Manufacturing Companies listed on investors really want the stock price to rise and never go down so that investors do not suffer losses. The purpose of this study was to determine the effect of Return on Investment, Net Profit Margin, Dividend the Indonesia Stock Exchange 2016-2019. Quantitative research used in data processing with statistics. Research is causal. Collecting data using documentation and literature. The population of this research is 177 manufacturing companies listed on the Indonesia Stock Exchange 20162019.The research sample was 34 manufacturing companies listed on the Indonesia Stock Exchange 2016-2019. Multiple linear regression model. The result is that Return On Investment has no effect on stock prices in manufacturing companies listed on the Indonesia Stock Exchange 2016-2019. Net Profit Margin has no effect on stock prices in manufacturing companies listed on the Indonesia Stock Exchange 2016-2019. Dividend Per Share has an effect on stock prices in manufacturing companies listed on the Indonesia Stock Exchange 2016-2019. Asset growth has no effect on stock prices in manufacturing companies listed on the Indonesia Stock Exchange 20162019. Return On Investment, Net Profit Margin, Dividend Per Share and Asset Growth affect stock prices in manufacturing companies listed on the Indonesia Stock Exchange 2016-2019.
\end{abstract}

Keywords: Return On Investment ; Net Profit Margin ; Dividend Per Share ; Asset Growth and Share Prices

\section{PENDAHULUAN}

Perkembangan ekonomi negara Indonesia tidak terlepas dari pasar modal. Salah satu sarana pendanaan yang dilakukan perusahaan ialah pasar modal. Perusahaan dapat melakukan pendanaan dengan cara berinvestasi dibidang penerbitan dan perdagangan surat berharga berupa saham, reksadana, waran maupun instrumen lainnya. Setiap investor memiliki tujuan utama dalam berinvestasi yakni memperoleh profit (keuntungan). Perusahaan go public ter-listing di BEI seperti perusahaan manufaktur menerbitkan sejumlah sahamnya untuk dimiliki para investor. Harga sahamnya berfluktuaktif yang dapat berubah tiap saat, padahal para investor sangat ingin harga saham naik dan tidak pernah turun agar investor tidak mengalami kerugian. Faktor yang turut mempengaruhi harga saham adalah return on investment, net profit margin, dividen per share dan pertumbuhan aset perusahaan.

ROI ialah salah satu rasio laba berguna mengukur kemampuan perusahaan dengan keseluruhan dana ditanamkan pada aset perusahaan. Besar kecilnya laba yang diukur dengan ROI ini akan memberikan pengaruh terhadap harga saham. Perusahaan memiliki laba tinggi maka ROI perusahaan tinggi kemudian mendorong naiknya harga saham. 
NPM merupakan rasio mengukur laba bersih dari tiap penjualan yang terjadi di perusahaan. Dari sisi investor NPM berguna sebagai alat analisis mengukur kemampuan perusahaan dalam memaksimalkan laba. NPM perusahaan tinggi maka harga saham perusahaan ikut naik. DPS merupakan total dividen yang dibagikan kepada investor untuk tiap lembar sahamnya. DPS menjadi pertimbangan investor untuk melakukan investasi. Dividen yang dibayarkan menurun menjadi faktor penurunan harga saham karena banyak pemegang saham menjual sahamnya. DPS yang naik maka harga saham juga naik.

Pertumbuhan aset merupakan perubahan total aktiva yang dimiliki perusahaan. Pertumbuhan aset yang tinggi dapat meningkatkan laba perusahaan dengan sendirinya dapat meningkatkan harga saham. Pertumbuhan aset yang dimiliki perusahaan baik dapat membayar dividen kepada para pemegang saham dengan lancar. Hal ini pertumbuhan aset turun maka harga saham mengalami penurunan. Di saat terjadinya penurunan aset maka investor akan mengurangi permintaan saham perusahaan.

Berdasarkan uraian yang telah ada sebelumnya dapat disajikan Tabel 1 sebagai berikut:

Tabel 1.

Tabel Fenomena Total Aset, Laba bersih, Penjualan, Dividen dan Harga Saham pada Perusahaan Manufaktur yang terdaftar di Bursa Efek Indonesia periode 2016-2019

(Dalam Jutaan Rupiah)

\begin{tabular}{|c|c|r|r|r|r|r|}
\hline $\begin{array}{c}\text { Kode } \\
\text { Emiten }\end{array}$ & Tahun & $\begin{array}{c}\text { Laba } \\
\text { Bersih }\end{array}$ & Penjualan & Total Aset & Dividen & $\begin{array}{c}\text { Harga } \\
\text { Saham }\end{array}$ \\
\hline SMGR & 2016 & $\mathbf{4 . 5 3 5 . 0 3 6}$ & 26.134 .306 & 44.226 .895 & 1.808 .588 & $\mathbf{9 . 1 7 5}$ \\
\cline { 2 - 7 } & 2017 & $\mathbf{2 . 0 4 3 . 0 2 5}$ & 27.813 .664 & 48.963 .502 & 1.808 .838 & $\mathbf{9 . 9 0 0}$ \\
\cline { 2 - 7 } & 2018 & 3.085 .704 & 30.687 .626 & 50.783 .836 & 805.678 .000 & 11.500 \\
\cline { 2 - 7 } & 2019 & 2.371 .233 & 40.368 .107 & 79.807 .067 & 1.231 .646 & 12.200 \\
\hline \multirow{4}{*}{ LION } & 2016 & 42.345 .417 & 379.137 .149 & 685.812 .995 & 20.806 .400 & 1.050 \\
\cline { 2 - 7 } & 2017 & 9.282 .943 & $\mathbf{3 4 9 . 6 9 0 . 7 9 6}$ & 681.937 .947 & 20.806 .400 & $\mathbf{7 6 5}$ \\
\cline { 2 - 7 } & 2018 & 14.679 .673 & $\mathbf{4 2 4 . 1 2 8 . 4 2 0}$ & 696.192 .628 & 7.802 .400 & $\mathbf{6 8 0}$ \\
\cline { 2 - 7 } & 2019 & 926.463 .199 & 372.489 .022 & 688.017 .892 & 5.201 .600 & 480 \\
\hline \multirow{3}{*}{ JPFA } & 2016 & 2.171 .608 & 27.063 .310 & $\mathbf{1 9 . 2 5 1 . 0 2 6}$ & 159.603 .000 & $\mathbf{1 . 4 5 5}$ \\
\cline { 2 - 7 } & 2017 & 1.107 .810 & 29.602 .688 & $\mathbf{2 1 . 0 8 8 . 8 7 0}$ & 485.987 .000 & $\mathbf{1 . 3 0 0}$ \\
\cline { 2 - 7 } & 2018 & 2.253 .201 & 34.012 .965 & 23.038 .028 & 1.100 .278 & 2.150 \\
\cline { 2 - 7 } & 2019 & 1.883 .857 & 36.742 .561 & 25.185 .009 & 1.171 .819 & 1.575 \\
\hline \multirow{4}{*}{ ARNA } & 2016 & 91.375 .910 & 1.511 .978 & 1.543 .216 & $\mathbf{3 6 . 6 9 3 . 0 1 5}$ & $\mathbf{5 2 0}$ \\
\cline { 2 - 7 } & 2017 & 122.183 .909 & 1.732 .985 & 1.601 .346 & $\mathbf{3 6 . 7 0 7 . 1 5 4}$ & $\mathbf{3 4 2}$ \\
\cline { 2 - 7 } & 2018 & 158.207 .798 & 1.971 .478 & 1.652 .905 & 88.095 .251 & 420 \\
\cline { 2 - 7 } & 2019 & 217.675 .239 & 2.151 .801 & 1.799 .137 & 117.247 .025 & 440 \\
\hline
\end{tabular}

Sumber : Hasil Pengolahan Data (2020)

Laba bersih PT. Semen Indonesia,Tbk (SMGR) di tahun 2017 sebesar 45,10\% menurun daripada tahun 2016 dengan harga saham di tahun 2017 sebesar 107,90\% meningkat daripada tahun 2016. Penjualan PT. Lion Metal Works,Tbk (LION) di tahun 2018 sebesar 121,29\% meningkat daripada tahun 2017 dengan harga saham di tahun 2018 sebesar 88,89\% menurun daripada tahun 2017. Total aset PT. Japfa Comfeed Indonesia, Tbk (JPFA) di tahun 2017 sebesar 109,49\% meningkat daripada tahun 2016 dengan harga saham di tahun 2017 sebesar 89,35\% menurun daripada tahun 2016. Dividen PT. Arwana Citra Mulia,Tbk (ARNA) di tahun 2017 sebesar 100,04\% meningkatkan daripada tahun 2016 dengan harga saham di tahun 2017 sebesar $65,77 \%$ menurun daripada tahun 2016.

\section{STUDI LITERATUR}

Teori Pengaruh Return On Investment (ROI) terhadap Harga Saham

Witjaksono, Hasanah (2016:131) Return On Invesment yang mengalami kenaikan diikuti 
dengan harga sahamnya naik. Priatinah (2012:54), laba naik dan berdampak positif terhadap kinerja keuangan perusahaan sehingga harga sahamnya naik. Rowena, Hendra (2017:2), profitabilitas suatu perusahaan menurun, maka akan lebih banyak yang menjual sahamnya sehingga harganya juga akan menurun. Tentu saja, hal yang sebaliknya juga dapat terjadi.

$\mathrm{H}_{1}$ : Return On Investment berpengaruh terhadap harga saham pada perusahaan manufaktur yang terdaftar di Bursa Efek Indonesia Periode 2016-2019.

\section{Teori Pengaruh Net Profit Margin (NPM) terhadap Harga Saham}

Halimatussakdiah (2018:18), Pada prinsipnya jika perusahaan dapat menghasilkan laba setiap tahun. Maka, hal ini tentunya dapat meningkatkan permintaan akan saham yang dimiliki oleh perusahaan. Wibowo, Kuntari (2014:32) Semakin tinggi Net Profit Margin akan menunjukkan adanya efisiensi yang semakin tingginya harga saham. Amalya (2018:161), NPMnya besar ditunjukkan kinerjanya produktif sehingga terjadi kenaikan harga saham.

$\mathrm{H}_{2}$ : Net Profit Margin berpengaruh terhadap harga saham pada perusahaan manufaktur yang terdaftar di Bursa Efek Indonesia Periode 2016-2019.

\section{Teori Pengaruh Dividen Per Share (DPS) terhadap Harga Saham}

Damayanti, Atmaja, Adiputra (2014:4), DPS naik maka harga saham naik dikarenakan investor tertarik pada DPS yang tinggi. Lilianti (2018:13-14), dividend per share mengalami kenaikan yang berpengaruh terhadap harga saham. Rowena, Hendra (2017:234) perusahaan membayar dividen besar, maka perusahaan mungkin menaikkan modal di waktu yang akan datang melalui penjualan sahamnya untuk membiayai kesempatan investasi yang menguntungkan.

$\mathrm{H}_{3}$ : Dividen Per Share berpengaruh terhadap harga saham pada perusahaan manufaktur yang terdaftar di Bursa Efek Indonesia Periode 2016-2019.

\section{Teori Pengaruh Pertumbuhan Aset terhadap Harga Saham}

Fatiyah, dkk., (2018:6) pertumbuhan aset yang cepat maka saham menjadi incaran investor dapat mengakibatkan harga saham meningkat. Sulia (2017:131) investor memandang pertumbuhan aset perusahaan sebagai aspek menguntungkan kemudian menaikkan harga sahamnya.

$\mathrm{H}_{4}$ : Pertumbuhan Aset berpengaruh terhadap harga saham pada perusahaan manufaktur yang terdaftar di Bursa Efek Indonesia Periode 2016-2019.

\section{Kerangka Konseptual}

Berdasarkan beberapa teori pengaruh diatas, maka dapat disimpulkan dengan variabel independen dengan variabel dependen sebagai berikut :

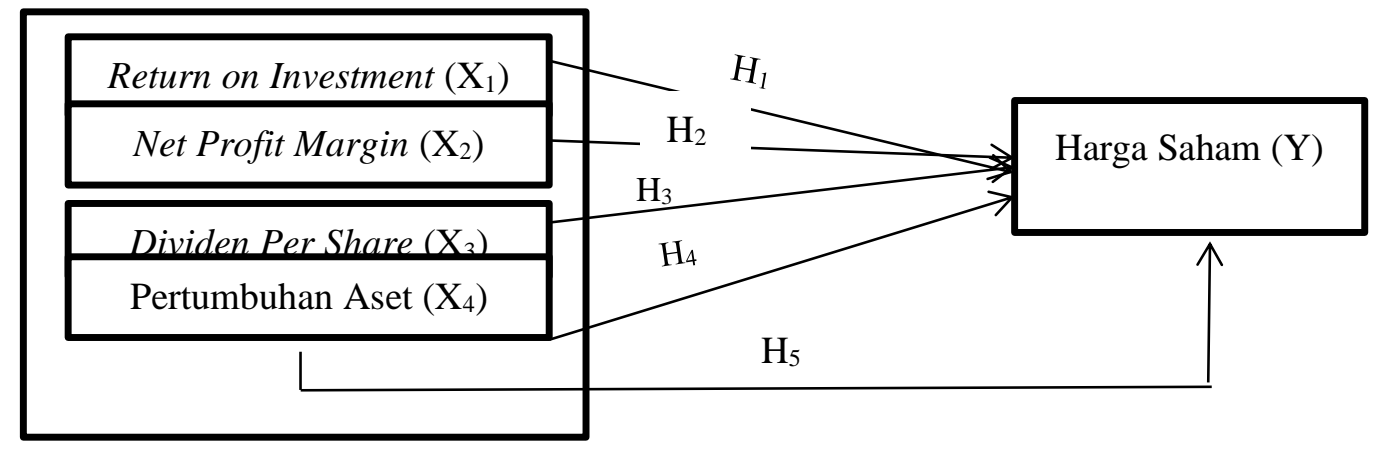

Gambar 1. Kerangka Konseptual

\section{Jenis Penelitian}

\section{METODE}

Kuantitatif penelitian yang digunakan pada pengolahan data dengan statistik. Penelitian bersifat sebab akibat. Pengumpulan data dengan menggunakan dokumentasi dan kepustakaan.

\section{Populasi dan Sampel}


Populasi penelitian ini adalah 177 Perusahaan Manufaktur yang tercatat di Bursa Efek Indonesia (BEI) periode 2016-2019.Penarikan sampel menggunakan metode purposive sampling method. Kriteria penarikan sampel sebagai berikut:

1. Perusahaan Manufaktur yang tercatat di Bursa Efek Indonesia (BEI) periode 2016-2019.

2. Perusahaan Manufaktur yang mempublikasikan laporan keuangan selama periode 2016-2019.

3. Perusahaan Manufaktur yang membagikan dividen secara berturut-turut periode 2016-2019. Adapun kriteria tertentu dalam pengambilan sampel pada tabel 2 sebagai berikut:

Tabel 2. Sampel Penelitian

\begin{tabular}{|l|r|}
\hline \multicolumn{1}{|c|}{ Keterangan } & \multicolumn{1}{|c|}{ Jumlah } \\
\hline $\begin{array}{l}\text { Perusahaan Manufaktur yang tercatat di Bursa Efek Indonesia } \\
\text { (BEI) periode 2016-2019 }\end{array}$ & 177 \\
\hline $\begin{array}{l}\text { Perusahaan Manufaktur yang tidak mempublikasikan laporan } \\
\text { keuangan selama periode 2016-2019 }\end{array}$ & (51) \\
\hline $\begin{array}{l}\text { Perusahaan Manufaktur yang tidak membagikan dividen secara } \\
\text { berturut-turut selama periode 2016-2019 }\end{array}$ & $\mathbf{( 9 2 )}$ \\
\hline Jumlah perusahaan yang terpilih menjadi sampel penelitian & $\mathbf{1 3 6}$ \\
\hline Jumlah observasi pengamatan (34 x 4)
\end{tabular}

Sumber : www.idx.co.id

Sampel penelitian sebanyak 34 Perusahaan Manufaktur yang tercatat di Bursa Efek Indonesia (BEI) periode 2016-2019.

\section{Teknik Pengumpulan Data}

Pengumpulan data dengan teknik dokumentasi melalui laporan keuanagn perusahaan yang dapat di browsing melalui website www.idx.co.id

\section{Jenis dan Sumber Data}

Jenis data penelitian adalah data kuantitatif berupa angka. Sumber data penelitian berupa data sekunder. Data sekunder dalam penelitian ini meliputi studi dokumentasi.

\section{Identifikasi dan Definisi Operasional Variabel \\ I. Variabel Independen \\ Teori Return On Investment (ROI)}

Menurut Irham Fahmi (2012:137), “Indikator untuk menghitung Return on investment (ROI) adalah :

$$
\text { Return On Investment }=\frac{\text { Laba setelah pajak }}{\text { Total aset }}
$$

\section{Teori Net Profit Margin (NPM)}

Tyas, Saputra (2016:81), net profit margin ialah rasio mengukut margin laba terhadap penjualan. Menurut Murhadi (2015:64), "Net Profit Margin diperoleh dengan cara sebagai berikut:

$$
\text { Net Profit Margin }=\frac{\text { Laba setelah pajak }}{\text { penjualan }}
$$

\section{Teori Dividen Per Share (DPS)}

Damayanti, Atmaja, Adiputra (2014:5), dividen per lembar saham ialah keseluruhan dividen yang dibayar tunai dibandingkan dengan jumlah saham beredar.

$$
\text { Dividend Per Share }=\frac{\text { Dividen Tunai }}{\text { Jumlah saham yang beredar }}
$$

\section{Teori Pertumbuhan Aset}

Anastassia, Firnanti (2014:100) pertumbuhan aset ialah jumlah dana yang tertanam pada aset dengan penggunaan dalam pertumbuhannya. 


$$
\text { Pertumbuhan Aset }=\frac{\text { Aset tahun ini-Aset tahun sebelumnya }}{\text { Aset tahun sebelumnya }}
$$

\section{Variabel Dependen}

\section{Teori Harga Saham}

Keumala, dkk., (2019:135), harga saham ialah harga terbentuk di pasar modal digunakan dalam penilaian pemegang saham terhadap perusahaan.

$$
\text { Harga saham = Harga penutupan saham }
$$

\section{Uji Asumsi Klasik}

Uji Normalitas

Uji Normalitas yang digunakan membuktikan data normal atau tidak. Pengujiannya menggunakan One Sample Komogorov-Smirnov secara statistik dan pengujian grafik normalitas adalah histogram beserta normal probability plot.

\section{Uji Multikolonieritas}

Multikolonieritas berguna untuk menguji apakah model regresi terdapat adanya korelasi antar variabel bebas (independen). Jika VIF menunjukkan angka $<10$ dan nilai tolerance $>0,10$ maka menandakan tidak ada gejala multikolinieritas.

\section{Uji Heteroskedastisitas}

Uji heteroskedastisitas menguji apakah dalam model regresi terjadi ketidaksamaan variance dari residual satu pengamatan ke pengamatan lain. Pengujian scatterplot jika titik tersebar secara acak maka tidak terjadi heterokedastisitas. Pengujian glejser jika signifikansi di atas 0,05 maka tidak terjadi heterokedastisitas.

\section{Uji Autokorelasi}

Pengujian autokorelasi menggunakan uji Durbin-Watson (DW test).

\section{Model Analisis Data Penelitian}

Analisis Regresi Linier Berganda

Analisis regresi linear berganda menunjukkan variabel penelitian ini lebih dari satu variabel independen dengan persamaan sebagai berikut :

\section{Keterangan :}

$$
\mathbf{Y}=\mathbf{a}+\mathbf{b}_{1} \mathbf{X}_{1}+\mathbf{b}_{2} \mathbf{X}_{2}+\mathbf{b}_{3} \mathbf{X}_{3}+\mathbf{b}_{4} \mathbf{X}_{4}+\mathbf{e}
$$

Y : Harga Saham

a : konstanta

$\mathrm{X}_{1} \quad$ : Return on investment

$\mathrm{X}_{2} \quad$ : Net Profit Margin

$\mathrm{X}_{3} \quad$ : Dividen per Share

$\mathrm{X}_{4} \quad$ : Pertumbuhan Aset

$\mathrm{b}_{1,2,3,4}$ : besaran koefisien regresi dari masing-masing variabel

e : error

\section{Koefisien Determinasi}

Koefisien determinasi berfungsi melihat sejauhmana keseluruhan variabel independen menjelaskan variabel dependen. Semakin besar koefesien determinasi, maka semakin baik kemampuan variabel bebas menjelaskan variabel terikat.

\section{Pengujian secara simultan (uji F)}

Uji hipotesis secara simultan digunakan mengetahui pengaruh variabel-variabel independen secara simultan terhadap variabel dependen.

Menurut Hantono (2017:72-73), Dasar pengambilan keputusan dalam uji F :

1. Jika nilai $F_{\text {hitung }}>F_{\text {tabel }}$ maka variabel independen secara simultan berpengaruh terhadap variabel dependen. 
2. Jika nilai $\mathrm{F}_{\text {hitung }}<\mathrm{F}_{\text {tabel }}$ maka variabel independen secara simultan tidak berpengaruh terhadap variabel dependen.

Dasar pengambilan keputusan dalam uji $\mathrm{F}$ berdasarkan nilai signifikansi :

1. Jika nilai signifikansi $<0,05$ maka variabel independen secara simultan berpengaruh signifikan terhadap variabel dependen.

2. Jika nilai signifikansi $>0,05$ maka variabel independen secara simulan tidak berpengaruh signifikan terhadap variabel dependen.

\section{Pengujian secara parsial (uji t)}

Uji hipotesis secara parsial digunakan mengetahui bagaimana pengaruh setiap variabel independen terhadap variabel dependen secara parsial (individu).

Menurut Hantono (2017:74-75), Dasar pengambilan keputusan uji t :

1. Jika nilai $t_{\text {hitung }}>t_{\text {tabel }}$ maka variabel independen secara parsial berpengaruh terhadap variabel dependen.

2. Jika nilai $t_{\text {hitung }}<t_{\text {tabel }}$ maka variabel independen secara parsial tidak berpengaruh terhadap variabel dependen.

Dasar pengambilan keputusan dalam uji t berdasarkan nilai signifikansi :

1. Jika nilai signifikansi $<0,05$ maka variabel independen secara parsial berpengaruh signifikan terhadap variabel dependen.

2. Jika nilai signifikansi $>0,05$ maka variabel independen secara parsial tidak berpengaruh signifikan terhadap variabel dependen.

\section{Hasil Penelitian}

\section{HASIL}

Dalam penelitian deskriptif statistik diawal ini :

\section{Data Deskriptif}

Sampelnya memenuhi kriteria pada peneltian ini berjumlah 34 laporan keuangan Perusahaan Manufaktur yang tercatat di Bursa Efek Indonesia (BEI) periode 2016-2019 dengan periode penelitian 4 tahun sehingga data berjumlah 136 data. Adapun data yang diuji mulai dari seluruuh data, min., max., meann dan std. deviasi dari masing variabel :

Tabel 3. Deskriptif Statistik

\begin{tabular}{|l|r|r|r|r|r|}
\hline \multicolumn{7}{|c|}{ Descriptive Statistics } \\
\hline & $\mathrm{N}$ & Minimum & Maximum & \multicolumn{1}{c|}{ Mean } & Std. Deviation \\
\hline ROI & 136 & .00 & .53 & .0982 & .08968 \\
\hline NPM & 136 & .00 & .39 & .1002 & .08096 \\
\hline DPS & 136 & .09 & 928.70 & 92.9348 & 158.58087 \\
\hline Pertumbuhan Aset & 136 & -.15 & 1.12 & .1074 & .17456 \\
\hline Hargasaham & 136 & 150.00 & 21950.00 & 3950.0368 & 4953.56504 \\
\hline Valid N (listwise) & 136 & & & & \\
\hline
\end{tabular}

Sumber: Hasil Pengolahan Data (2020)

Berdasarkan Tabel 3 terperinci :

1. Return on investment dengan jumlah sampel 136 , min 0,00 , max 0,53 , mean 0,0982 dan standar deviasi 0,08968 .

2. Net Profit Margin dengan jumlah sampel 136, min 0,00, max 0,39, mean 0,1002 dan standar deviasi 0,08096.

3. Dividen per Share dengan jumlah sampel 136, min 0,09, max 928,70, mean 92,9348 dan standar deviasi 158,58087.

4. Pertumbuhan Aset dengan jumlah sampel 136, min -0,15, max 1,12, mean 0,1074 dan standar deviasi 0,17456 . 
Owner: Riset \& Jurnal Akuntansi

e-ISSN : 2548-9224 |p-ISSN : 2548-7507

Volume 5 Nomor 1, Februari 2021

5. Harga Saham dengan jumlah sampel 136, min 150.00, max 21950.00, mean 3950,0368 dan standar deviasi 4953,56504.

\section{Uji Asumsi Klasik}

Normalitas

Uji Normalitas menggunakan 2 metode yaitu uji grafik dan statistik. Grafik pertama pengujian normalitas terlihat normal berbentuk parabola terbalik. Histogram ini disajikan pada gambar 2.

Histogram

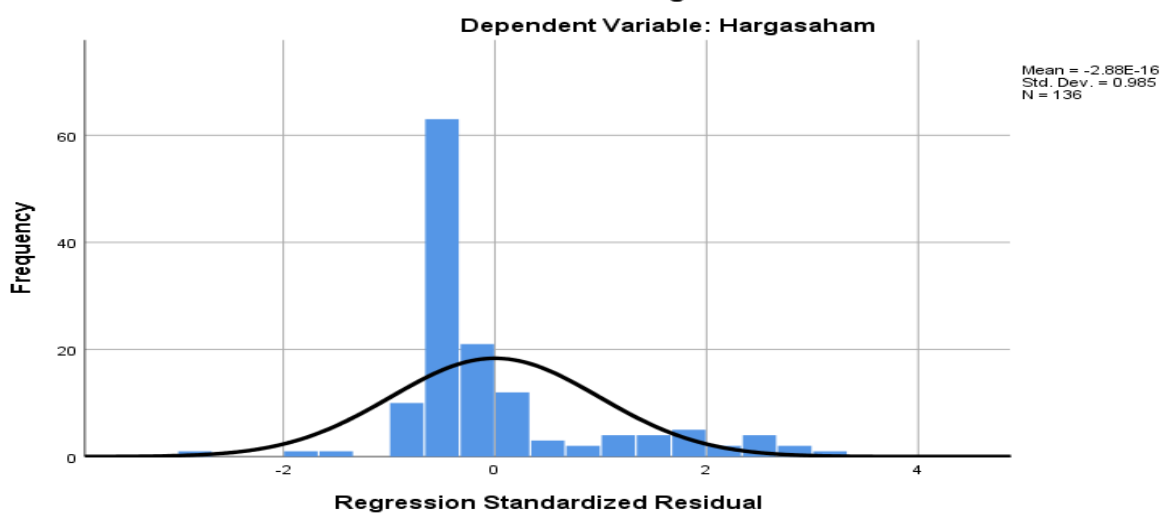

Gambar 2. Histogram Sebelum Transformasi

Sumber: Hasil Pengolahan Data (2020)

Grafik histogram ini terlihat miring kekanan kiri lagipula tidak membentuk parabola terbalik dapat dikatakan data tidak normal. Penormalan data dengan tranformasi ke ln untuk semua variabel maka grafik histrogramnya:

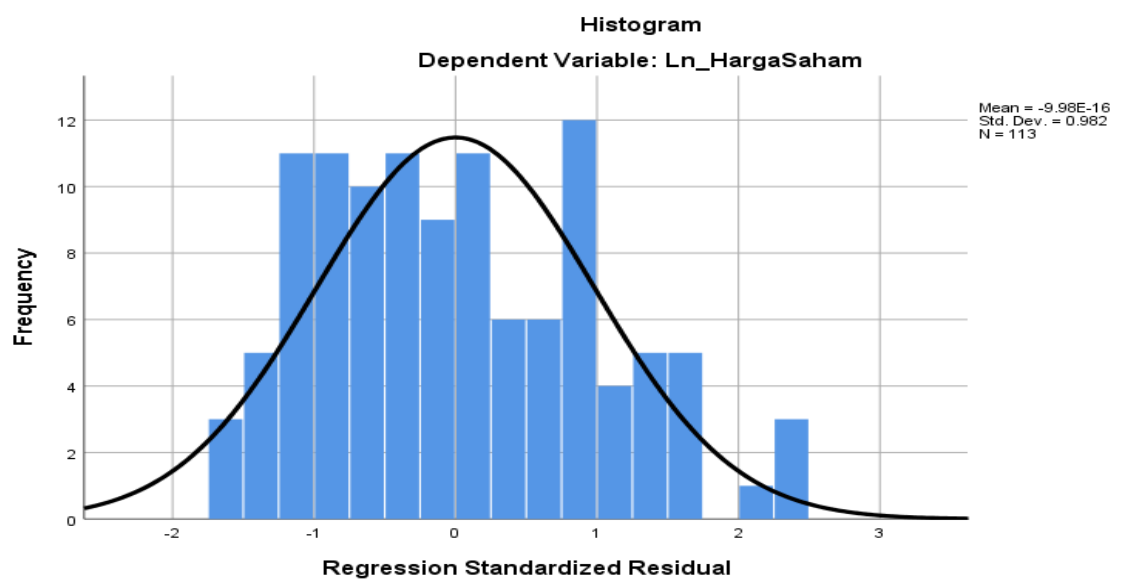

Gambar 3. Histogram Sesudah Transformasi

Sumber: Hasil Pengolahan Data (2020)

Grafik histogram ini terlihat tidak miring kekanan kiri lagipula membentuk parabola terbalik dapat dikatakan data normal.

Grafik kedua normal p-p-plot tersaji: 
Owner: Riset \& Jurnal Akuntansi

e-ISSN : 2548-9224 |p-ISSN : 2548-7507

Volume 5 Nomor 1, Februari 2021

DOI : https://doi.org/10.33395/owner.v5i1.334

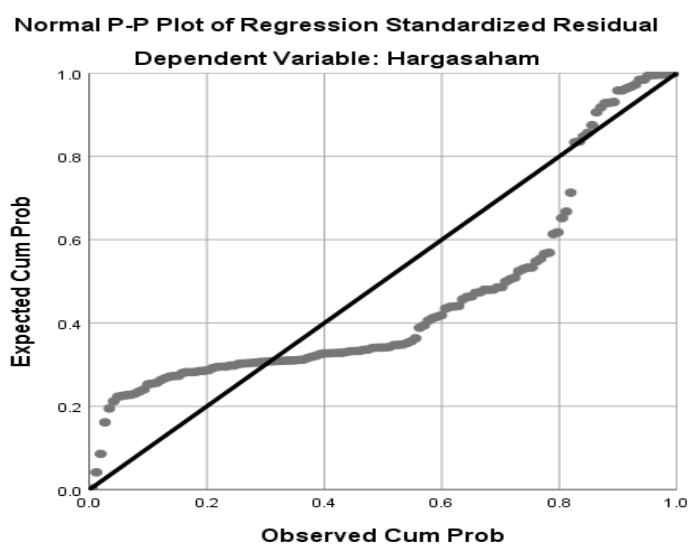

Gambar 4. Normal p-p-Plot Sebelum Transformasi

Sumber: Hasil Pengolahan Data (2020)

Grafik normal p-p-plot terlihatt titik menjauh dari garis diagonal terbukti data tidak normal. Penormalan data dengan transformasi ke ln untuk semua variabel maka grafik normal p-p-plot.

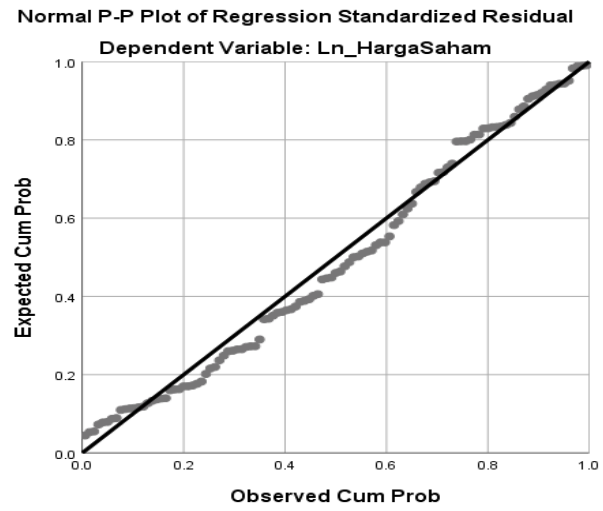

Gambar 5. Normal Probability Plot Sesudah Transformasi

Sumber: Hasil Pengolahan Data (2020)

Grafik normal p-p-plot terlihat titik mendekati dari garis diagonal terbukti data normal. Statistik one-sample kolmogorov smirnov untuk data normal berada diatas 0,05 .

Tabel 4. Hasil One-Sample Kolmogorov-Smirnov Test

\begin{tabular}{|l|l|r|}
\hline \multicolumn{2}{|c|}{ One-Sample Kolmogorov-Smirnov Test } \\
\hline $\mathrm{N}$ & Mean & Unstandardized Residual \\
\hline \multirow{2}{*}{ Normal Parameters ${ }^{\mathrm{a}, \mathrm{b}}$} & Std. Deviation & .0000000 \\
\hline \multirow{2}{*}{ Most Extreme Differences } & Absolute & 1.07149139 \\
\cline { 2 - 3 } & Positive & .076 \\
\cline { 2 - 3 } & Negative & .076 \\
\hline Test Statistic & -.066 \\
\hline Asymp. Sig. (2-tailed) & .076 \\
\hline \multicolumn{2}{|l|}{ a. Test distribution is Normal. } \\
\hline b. Calculated from data. \\
\hline \multicolumn{2}{|c|}{ c. Lilliefors Significance Correction. } \\
\hline
\end{tabular}

Sumber : Hasil Pengolahan Data (2020)

Berdasarkan tabel 4.Hasil uji One-Sample Kolmogorov-Smirnov bahwa nilai dari 
Owner: Riset \& Jurnal Akuntansi

e-ISSN : 2548-9224|p-ISSN : 2548-7507

Volume 5 Nomor 1, Februari 2021

DOI : https://doi.org/10.33395/owner.v5i1.334

Asymp.Sig (2-tailed) diperoleh sebesar 0,115 > 0,05 dapat diambil keputusan bahwa data dalam penelitian ini berdistribusi normal

\section{Uji Multikolinearitas}

Uji normalitas merupakan uji syarat kedua setelah normalitas. Pengujian multikolinearitas baik tidak terjadi korelasi antar variabel independen dengan ketentuan VIF berada dibawah 10 dan tolerance diatas 0,1 .

Tabel 5. Hasil Uji Multikolinieritas

\begin{tabular}{|l|l|c|c|}
\hline \multicolumn{2}{|c|}{ Model } & \multicolumn{2}{c|}{ Collinearity Statistics } \\
\cline { 3 - 4 } \multicolumn{1}{|c|}{} & Tolerance & VIF \\
\hline \multirow{10yy}{*}{} & (Constant) & & \\
\cline { 2 - 4 } & Ln_ROI & .272 & 3.673 \\
\cline { 2 - 4 } & Ln_NPM & .262 & 3.822 \\
\cline { 2 - 4 } & Ln_DPS & .930 & 1.075 \\
\cline { 2 - 4 } & Ln_PertumbuhanAset & .993 & 1.007 \\
\hline
\end{tabular}

Sumber : Hasil Pengolahan Data (2020)

Multikolinearitas yang baik tidak terjadi multikolinearitas antar variabel independen dengan ketentuan VIF berada dibawah 10 dan tolerance diatas 0,1 .

\section{Uji Autokorelasi}

Autokorelasi merupakan pendugaan parameter yang bersifat BLUE maka dalam regresi linear berganda seharusnya tidak ada autokorelasi. Pengujian autokorelasi dengan ketentuan $\mathrm{du}<\mathrm{dw}<4-\mathrm{du}$.

Tabel 6. Hasil Uji Autokorelasi

\begin{tabular}{|l|c|c|c|c|c|}
\hline \multicolumn{7}{|c|}{ Model Summary $^{\mathrm{b}}$} \\
\hline $\begin{array}{l}\text { Mode } \\
\mathrm{I}\end{array}$ & $\mathrm{R}$ & $\begin{array}{c}\mathrm{R} \\
\text { Square }\end{array}$ & $\begin{array}{c}\text { Adjusted R } \\
\text { Square }\end{array}$ & $\begin{array}{c}\text { Std. Error of } \\
\text { the Estimate }\end{array}$ & $\begin{array}{c}\text { Durbin- } \\
\text { Watson }\end{array}$ \\
\hline 1 & $.553^{\mathrm{a}}$ & .305 & .280 & 1.09115 & 1.399 \\
\hline \multicolumn{7}{|l|}{ a. Predictors: (Constant), Ln_PertumbuhanAset, Ln_DPS, Ln_ROI, Ln_NPM } \\
\hline \multicolumn{5}{|l}{ b. Dependent Variable: Ln_HargaSaham }
\end{tabular}

Sumber: Hasil Pengolahan Data (2020)

$\mathrm{dw}=1,399$. Nilai $-2 \leq \mathrm{DW} \leq+2$ dengan persamaan yang diperoleh menunjukkan $-2 \leq 1,399>+2$ tidak terjadi autokorelasi.

\section{Uji Heteroskedastisitas}

Uji heteroskedastisitas dengan metode grafik dan statistik. Grafik Scatterplot yang memenuhi ketentuan titik tersebar secara acak dan tidak berpola menunjukkan tidak ada heterokedatisitas.

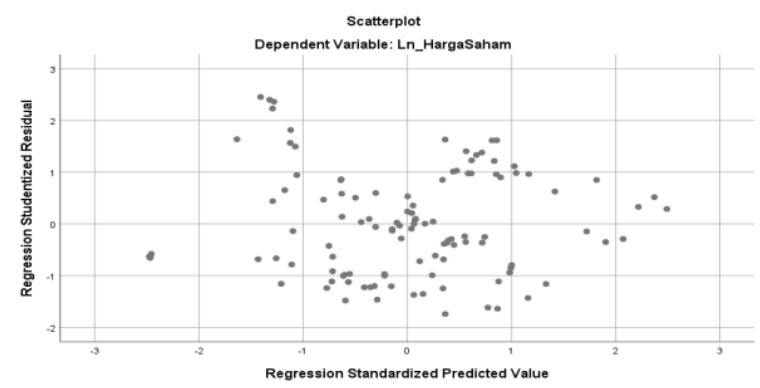

Gambar 6. Scatterplot

Sumber: Hasil Pengolahan Data (2020) 
Grafik Scatterplot yang memenuhi ketentuan titik tersebar secara acak dan tidak berpola menunjukkan tidak ada heterokedatisitas.

Uji white pada tabel 7 berikut ini:

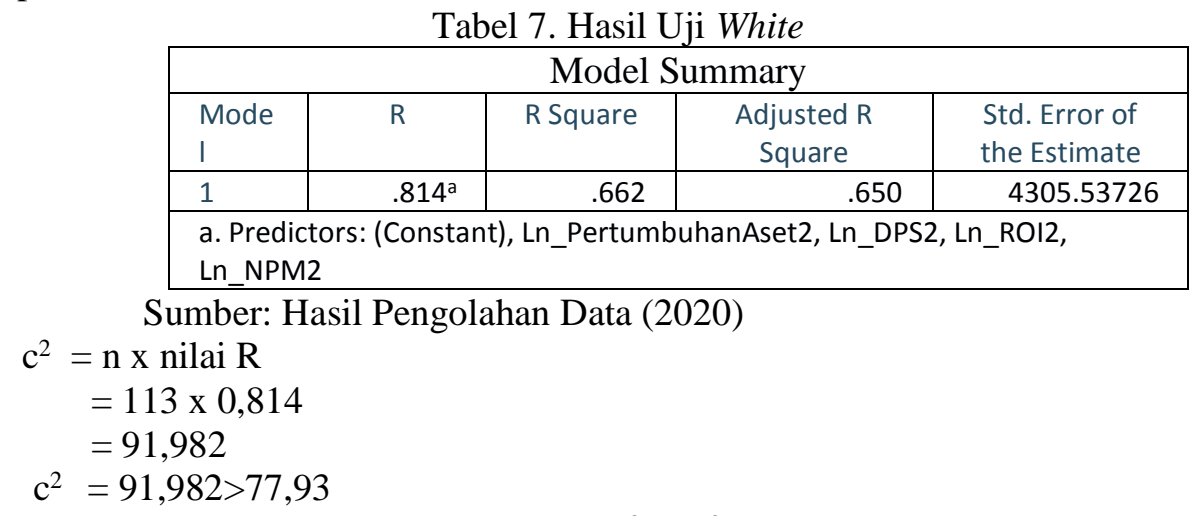

Berdasarkan hasil uji white menunjukkan $c^{2}>c^{2}$ tabel maka 91,982 >77,93 tidak terjadi heteroskedastisitas.

\section{Hasil Analisis Data}

Analisis Regresi Linier Berganda

Regresi linear berganda untuk mengetahui naik atau turunya variabel bebasnya. Regresinya dapat dilihat pada tabel 8 berikut ini:

Tabel 8. Hasil Analisis Regresi Linier Berganda

\begin{tabular}{|c|c|c|c|c|c|c|}
\hline \multicolumn{7}{|c|}{ Coefficients $^{\mathrm{a}}$} \\
\hline \multirow{2}{*}{\multicolumn{2}{|c|}{ Model }} & \multicolumn{2}{|c|}{ Unstandardized Coefficients } & \multirow{2}{*}{$\begin{array}{c}\text { Standardized Coefficients } \\
\text { Beta }\end{array}$} & \multirow[t]{2}{*}{$\mathrm{t}$} & \multirow[t]{2}{*}{ Sig. } \\
\hline & & $\mathrm{B}$ & Std. Error & & & \\
\hline 1 & (Constant) & 8.382 & .508 & & 16.493 & .000 \\
\hline & Ln_ROI & .157 & .247 & .097 & .634 & .527 \\
\hline & Ln_NPM & .472 & .275 & .269 & 1.716 & .089 \\
\hline & Ln_DPS & .227 & .054 & .349 & 4.196 & .000 \\
\hline & Ln_PertumbuhanAset & .015 & .113 & .011 & .134 & .894 \\
\hline
\end{tabular}

Sumber: Hasil Pengolahan Data (2020)

Ln_Harga Saham $=8,382+0,157$ Ln_ROI + 0,472 Ln_NPM + 0,227 Ln_DPS + 0,015

Ln_Pertumbuhan Aset

1. Nilai a sebesar 8,382 artinya Return on investment, Net Profit Margin, Dividen per Share dan Pertumbuhan Aset dianggap 0, maka harga saham adalah sebesar 8,382.

2. Nilai koefisien Return on investment 0,157 artinya setiap peningkatan Return on investment satu kali maka harga saham akan mengalami kenaikan sebesar 0,157.

3. Nilai koefisien Net Profit Margin sebesar 0,472 artinya setiap peningkatan Net Profit Margin satu kali maka harga saham akan mengalami kenaikan sebesar 0,472.

4. Nilai koefisien Dividen per Share sebesar 0,227 artinya setiap peningkatan Dividen per Share satu kali maka harga saham akan mengalami kenaikan sebesar 0,227.

5. Nilai koefisien Pertumbuhan Aset sebesar 0,015 artinya setiap peningkatan Pertumbuhan Aset satu kali maka harga saham akan mengalami kenaikan sebesar 0,015.

\section{Koefisien Determinasi $\left(\mathbf{R}^{2}\right)$} terikatnya.

Koefisien determinasinya mengukur besarnya pengaruh variabel bebasnya dengan variabel 
Owner: Riset \& Jurnal Akuntansi

e-ISSN : 2548-9224|p-ISSN : 2548-7507

Volume 5 Nomor 1, Februari 2021

DOI : https://doi.org/10.33395/owner.v5i1.334

Tabel 9. Koefisien Determinasi

\begin{tabular}{|l|c|c|c|c|}
\hline \multicolumn{5}{|c|}{ Model Summary } \\
\hline $\begin{array}{l}\text { Mode } \\
1\end{array}$ & $\mathrm{R}$ & $\begin{array}{c}\mathrm{R} \\
\text { Square }\end{array}$ & $\begin{array}{c}\text { Adjusted R } \\
\text { Square }\end{array}$ & $\begin{array}{c}\text { Std. Error of } \\
\text { the Estimate }\end{array}$ \\
\hline 1 & $.553^{\mathrm{a}}$ & .305 & .280 & 1.09115 \\
\hline $\begin{array}{l}\text { a. Predictors: (Constant), Ln_PertumbuhanAset, Ln_DPS, Ln_ROI, } \\
\text { Ln_NPM }\end{array}$ \\
\hline \multicolumn{4}{|l}{ b. Dependent Variable: Ln_HargaSaham } \\
\hline
\end{tabular}

Sumber: Hasil Pengolahan Data (2020)

Berdasarkan Tabel 9 nilai adjusted $\left(\mathrm{R}^{2}\right)$ sebesar $0,280=28 \%$. variabel independen berpengaruh terhadap harga saham $28 \%$ dan sisanya $72 \%$ dipengaruhi variabel independen lain.

\section{Pengujian Hipotesis Secara Simultan (Uji Statistik F)}

F menguji apakah variabel independen secara bersama-sama mempengaruhi variabel dependen.

Tabel 10.Hasil Uji Statistik F

\begin{tabular}{|c|c|c|c|c|c|c|}
\hline \multicolumn{7}{|c|}{ ANOVA $^{a}$} \\
\hline \multicolumn{2}{|c|}{ Model } & $\begin{array}{l}\text { Sum of } \\
\text { Squares }\end{array}$ & df & $\begin{array}{c}\text { Mean } \\
\text { Square }\end{array}$ & $F$ & Sig. \\
\hline \multirow[t]{3}{*}{1} & Regression & 56.516 & 4 & 14.129 & 11.867 & $.000^{\mathrm{b}}$ \\
\hline & Residual & 128.587 & 108 & 1.191 & & \\
\hline & Total & 185.102 & 112 & & & \\
\hline
\end{tabular}

Sumber: Hasil Pengolahan Data (2020)

$\mathrm{F}_{\text {hitung }}=11,867, \mathrm{sig}=0,000$ dan $\mathrm{F}_{\text {tabel }}(113-5=108)=2,46 . \quad \mathrm{F}_{\text {hitung }}>\mathrm{F}_{\text {tabel }}$ yaitu $12,751>2,46$ maka Ho ditolak dan Ha diterima, Return On Investment (ROI), Net Profit Margin (NPM), Dividen Per Share (DPS) dan Pertumbuhan Aset berpengaruh terhadap harga saham pada perusahaan manufaktur yang terdaftar di Bursa Efek Indonesia Periode 2016-2019.

Pengujian Hipotesis Secara Parsial (Uji Statistik t) dependen.

Uji t menguji apakah variabel independen secara individual mempengaruhi variabel

Tabel 11. Hasil Uji Statistik t

\begin{tabular}{|c|c|c|c|c|c|c|}
\hline \multicolumn{7}{|c|}{ Coefficients $^{\mathrm{a}}$} \\
\hline \multirow{2}{*}{\multicolumn{2}{|c|}{ Model }} & \multicolumn{2}{|c|}{ Unstandardized Coefficients } & \multirow{2}{*}{$\begin{array}{c}\text { Standardized Coefficients } \\
\text { Beta }\end{array}$} & \multirow[t]{2}{*}{$\mathrm{t}$} & \multirow[t]{2}{*}{ Sig. } \\
\hline & & $\mathrm{B}$ & Std. Error & & & \\
\hline \multirow[t]{5}{*}{1} & (Constant) & 8.382 & .508 & & 16.493 & .000 \\
\hline & Ln_ROI & .157 & 247 & .097 & .634 & .527 \\
\hline & Ln_NPM & .472 & .275 & .269 & 1.716 & .089 \\
\hline & Ln_DPS & .227 & .054 & .349 & 4.196 & .000 \\
\hline & Ln_PertumbuhanAset & .015 & .113 & .011 & .134 & .894 \\
\hline
\end{tabular}

Sumber: Hasil Pengolahan Data (2020)

$\mathrm{t}_{\text {tabel }}(113-4=109)=1,981$

1. Return On Investment $(\mathrm{ROI}) \mathrm{t}_{\text {hitung }}=0,634$, sig $=0,527, \mathrm{t}_{\text {hitung }}<\mathrm{t}_{\text {tabel }}$ yaitu $0,634<1,981$ maka Ho diterima dan $\mathrm{H}_{\mathrm{a}}$ ditolak berarti Return On Investment (ROI) tidak berpengaruh terhadap harga saham pada perusahaan manufaktur yang terdaftar di Bursa Efek Indonesia Periode 20162019.

2. Net Profit Margin (NPM) $\mathrm{t}_{\text {hitung }}=1,716$, sig $=0,089$, $\mathrm{t}_{\text {hitung }}<\mathrm{t}_{\text {tabel }}$ yaitu $1,719<1,981$ maka Ho diterima dan $\mathrm{H}_{\mathrm{a}}$ ditolak berarti Net Profit Margin (NPM) tidak berpengaruh terhadap harga saham pada perusahaan manufaktur yang terdaftar di Bursa Efek Indonesia Periode 2016-2019. 
3. Dividen Per Share (DPS) $\mathrm{t}_{\text {hitung }}=4,196$, $\mathrm{sig}=0,000, \mathrm{t}_{\text {hitung }}>\mathrm{t}_{\text {tabel }}$ yaitu $4,196>1,981$ maka Ho ditolak dan $\mathrm{H}_{\mathrm{a}}$ diterima berarti Dividen Per Share (DPS) berpengaruh terhadap harga saham pada perusahaan manufaktur yang terdaftar di Bursa Efek Indonesia Periode 2016-2019.

4. Pertumbuhan Aset $\mathrm{t}_{\text {hitung }}=0,134$, sig $=0,894, \mathrm{t}_{\text {hitung }}<\mathrm{t}_{\text {tabel }}$ yaitu 0,894 $<1,981$ maka Ho diterima dan $\mathrm{H}_{\mathrm{a}}$ ditolak berarti Pertumbuhan Aset tidak berpengaruh terhadap harga saham pada perusahaan manufaktur yang terdaftar di Bursa Efek Indonesia Periode 2016-2019.

\section{PEMBAHASAN}

\section{Pengaruh Return On Investment (ROI) Terhadap Harga Saham}

Hasil penelitian ini adalah Return On Investment (ROI) tidak berpengaruh terhadap harga saham pada perusahaan manufaktur yang terdaftar di Bursa Efek Indonesia Periode 2016-2019. Hasil penelitian tidak sejalan dengan Purnomo dan Ambarsari (2005) menyatakan, Witjaksono, Hasanah (2016:131) Return On Invesment yang mengalami kenaikan diikuti dengan harga sahamnya naik.

\section{Pengaruh Net Profit Margin (NPM) Terhadap Harga Saham}

Hasil penelitian ini adalah Net Profit Margin (NPM) tidak berpengaruh terhadap harga saham pada perusahaan manufaktur yang terdaftar di Bursa Efek Indonesia Periode 2016-2019 Hasil penelitian ini sejalan dengan Wibowo, Kuntari (2014:32) Semakin tinggi Net Profit Margin akan menunjukkan adanya efisiensi yang semakin tingginya harga saham

\section{Pengaruh Dividen Per Share (DPS) Terhadap Harga Saham}

Hasil penelitian ini adalah Dividen Per Share (DPS) berpengaruh terhadap harga saham pada perusahaan manufaktur yang terdaftar di Bursa Efek Indonesia Periode 2016-2019.

Hasil penelitian ini sejalan dengan Damayanti, Atmaja, Adiputra (2014:4), DPS naik maka harga saham naik dikarenakan investor tertarik pada DPS yang tinggi.

\section{Pengaruh Pengaruh Pertumbuhan Aset Terhadap Harga Saham}

Hasil penelitian ini adalah Pertumbuhan Aset tidak berpengaruh terhadap harga saham pada perusahaan manufaktur yang terdaftar di Bursa Efek Indonesia Periode 2016-2019.

Hasil penelitian ini tidak sejalan dengan Sulia (2017:131) investor memandang pertumbuhan aset perusahaan sebagai aspek menguntungkan kemudian menaikkan harga sahamnya.

\section{KESIMPULAN}

Berdasarkan dengan hasil penelitian mengenai pengaruh Return On Investment, Net Profit Margin, Dividen Per Share dan Pertumbuhan Aset terhadap Harga Saham pada Perusahaan Manufaktur yang tercatat di Bursa Efek Indonesia periode 2016-2019 dengan menggunakan teknik analisis regresi linear berganda, dapat disimpulkan pada uji t (Parsial) bahwa variabel Return On Investment tidak berpengaruh secara signifikan terhadap Harga Saham, Net Profit Margin tidak berpengaruh secara signifikan terhadap Harga Saham, Dividen Per Share berpengaruh signifikan terhadap Harga Saham dan Pertumbuhan Aset tidak berpengaruh secara signifikan terhadap Harga Saham. Hasil uji F (Simultan) membuktikan bahwa Return On Investment, Net Profit Margin, Dividen Per Share dan Pertumbuhan Aset berpengaruh terhadap Harga Saham.

\section{REFERENCES}

Amalya, N. T. (2018). Pengaruh Return On Asset, Return On Equity, Net Profit Margin dan Debt to Equity Ratio terhadap Harga Saham. Jurnal SEKURITAS (Saham, Ekonomi, Keuangan Dan Investasi). https://doi.org/10.32493/skt.v1i3.1096

Anastassia, \& Firnanti, F. (2014). Faktor-Faktor yang Mempengaruhi Volatilitas Harga Saham Pada Perusahaan Publik Non-Keuangan. Jurnal Bisnis Dan Akuntansi.

Fahmi, I. (2015). Manajemen Investasi Teori dan Soal Jawab. In Inflasi dan Investasi.

Fatiyah, N., Sulistiyo, H., \& sam'ani. (2018). Pengaruh Pertumbuhan Perusahaan dan Struktur Modal Terhadap Nilai Perusahaan dengan Profitabilitas dan Good Corporate Governance sebagai Variable Intervening (Studi Empiris perusahaan manufaktur di BEI tahun 2012 2016). Jurnal Ilmu Manajemen Dan Akuntansi Terapan (JIMAT, 9(1), 2086 3748. 
Halimatusakdiah. (2018). Pengaruh Profitabilitas, Likuiditas dan Deviden Per Share Terhadap Harga Saham Perusahaan LQ-45 Yang Terdaftar Di Bursa Efek Indonesia. Journal of Chemical Information and Modeling, 53(9), 1689-1699.

Hayati, K., \& Situmorang, S. (2019). Pengaruh Net Profit Margin , Likuiditas dan Pertumbuhan Penjualan terhadap Harga Saham pada Perusahaan Manufaktur yang Terdaftar di Bursa Efek Indonesia Periode 2013-2017. Riset \& Jurnal Akuntansi, 3(1), 133-139.

Lilianti, E. (2018). Pengaruh Dividend Per Share (DPS) dan Earning Per Share (EPS) Terhadap Harga Saham pada Perusahaan Sub Sektor Farmasi di Bursa Efek Indonesia (BEI). Jurnal Ecoment Global.https://doi.org/10.35908/jeg.v3i1.353

Murhadi, W. R. (2015). Analisis Laporan Keuangan Proyeksi dan Valuasi Saham. In Salemba Empat.

Putu Ryan Damayanti, A. T. A., \& Adiputra, P. (2013). Pengaruh Deviden Per Share Dan Earning Per Share Terhadap Harga Saham Pada Perusahaan Industri Barang Konsumsi Yang Terdaftar Di Bursa Efek Indonesia Periode 2010-2012. JIMAT (Jurnal Ilmiah Mahasiswa Akuntansi S1).

Priatinah, D., \& Kusuma, P. A. (2012). Pengaruh Return on Investment (ROI), Earning Per Share (EPS), dan Dividen Per Share (DPS) Terhadap Harga Saham Perusahaan Pertambangan Yang Terdaftar Di Bursa Efek Indonesia (BEI). Jurnal Nominal.

Rowena, J., \& Hendra. (2017). Earnings Volatility, Kebijakan Dividen, dan Pertumbuhan Asset Berpengaruh Terhadap Volatilitas Harga Saham Pada Perusahaan Manufaktur Di BEI

Return, P., Investment, O. N., Harga, T., Pada, S., Pulp, P., Yang, P., Di, T., \& Efek, B. (n.d.). The Asia Pacific.

Sulia. (2017). Analisis faktor - faktor yang mempengaruhi harga saham pada perusahaan lq45 yang terdaftar di bursa efek indonesia. Jurnal Wira Ekonomi Mikroskil Volume 7, Nomor 02.

Tyas, R., \& Saputra, R. (2016). Analisis Pengaruh Profitabilitas terhadap Harga Saham (Studi Kasus Perusahaan Telekomunikasi yang Terdaftar di Bursa Efek Indonesia (BEI) Periode 2012-2014). Jurnal Online Insan Akuntan.

Wibowo, H., \& Kuntari, Y. (2012). Pengaruh Dividend Per Share, Return on Asset, Return On Equity Dan Net Profit Margin Terhadap Harga Saham. 16(1). http://eprints.perbanas.ac.id/1787/1/jorunal.com 